\title{
Role of ICT in Agriculture: Policy implications
}

\author{
SURABHI SINGH ${ }^{1 *}$, SANTOSH AHLAWAT ${ }^{2}$ and SARITA SANWAL ${ }^{3}$
}

${ }^{1}$ FRM, SDAU(Sardarkrushinagar Dantiwada Agricultural University), India. ${ }^{2} \mathrm{HECM}, \mathrm{SDAU}$ (Sardarkrushinagar Dantiwada Agricultural University), India. ${ }^{3} \mathrm{HDFS}, \mathrm{SDAU}$ (Sardarkrushinagar Dantiwada Agricultural University), India.

\section{Abstract}

Agriculture is a gigantic sector of the Indian economy as its share to gross domestic product (GDP) is almost 17 per cent. Over 60 per cent of the population adopts agriculture as main occupation. In spite of a large of Indian economy, agriculture is lagging behind many aspects and characterised by poor connectivity and disintegration of market, unreliable and delayed information to the farmers, small land holdings, non adoption or less adoption of improved technology and so on. It has become indispensable to explore various ways to keep our farmers updated about modern technologies and relevant information. The development and timely dissemination of better personalized technologies specific to different agro-climatic conditions, size of land holding, soil type, type of crops and related pests/diseases is the real issue to brazen out ahead for the agricultural scientists/experts. The timely availability of right information and its proper utilisation is indispensable for agriculture. ICT based initiatives can be taken for propagation of information, transfer of technology, procurement of inputs and selling of outputs in a way so that farmers can be benefitted. The timely information and practical solutions of the agricultural problems helps the farmers to adopt good agricultural practices, make better choices of inputs and to plan the cultivation properly.

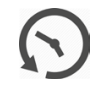

\section{Article History}

Received: 05 July 2017 Accepted:08 August 2017

\section{Keywords}

ICT, agriculture, agriculture related information, India, farmers.

\section{Introduction}

Agriculture is a gigantic sector of the Indian economy as its share to gross domestic product (GDP) is almost 17 per cent. The increased demand for food grains can be met only with sincere efforts in agricultural research and extension. In spite of a large of Indian economy, agriculture is lagging behind many aspects and characterised by poor connectivity and disintegration of market, unreliable and delayed information to the farmers, small land holdings, non adoption or less adoption of improved technology and so on. It has become indispensable to explore various ways to keep our farmers updated about modern technologies and relevant information to pace up them in current technological era.

Information technology revolution is upcoming rapidly

CONTACT surabhi singh surabhi1882@sdau.edu.in 9 FRM, SDAU(Sardarkrushinagar Dantiwada Agricultural University), India (C) 2017 The Author(s). Published by Enviro Research Publishers

This is an 6 Open Access article licensed under a Creative Commons Attribution-NonCommercial-ShareAlike 4.0 International License (https://creativecommons.org/licenses/by-nc-sa/4.0/), which permits unrestricted NonCommercial use, distribution, and reproduction in any medium, provided the original work is properly cited.

To link to this article: http://dx.doi.org/10.13005/ojcst/10.03.20 
and more noticeable now. With the introduction of information and communication technologies, the traditional agriculture has been reformed, eventually contributing to the significant improvements in agricultural productivity and sustainability. Empowering farmers with the right information at the right time and place is essential for improving the efficiency and viability of small and marginal holdings ${ }^{9}$.

Large data and information can be effectively generated, stored, analyzed, disseminated and used to upgrade agriculture by inclusion of Information and Communication Technology. It may increase production many folds by providing prompt, reliable and locality based information services to the farmers. Hence, ICT in agriculture has become a budding field of research and application related to e-agriculture.

Information and communication are always necessary in agriculture. Since people have started growing crops, raising livestock, and catching the fish, they have hunted information from one another. ICT can be construed broadly as "using electronic means for processing and disseminating information and thereby facilitating communication quickly and easily".

\section{Role of ICT in Agriculture}

Information and Communicational Technology (IT) has many roles to perform for agricultural development starting from decision support system to the trading of crops.

\section{Decision Support System}

ICT has a great role as decision support system to the farmers. Through ICT, farmers can be updated with the recent information about agriculture, weather, new varieties of crops and new ways to increase production and quality control. The dissemination of adequate, efficient and tailored technologies related to agro-climatic zone, size of farm and soil type etc. to the farmers is deficient in Indian agriculture and it is the real challenge in front of policy makers in India ${ }^{3}$.

Information and communication technologies can broadcast the precise and authentic information at right time to the farmers so that they can utilize it and get benefits. The decision support system through ITC facilitates farmers for planning type of crops, practising good agricultural practices for cultivating, harvesting, post harvesting and marketing their produce to get better results ${ }^{15}$.

Varied information is required in agriculture based on the different agro climatic regions, size of land holdings, types of crops cultivated, technology followed, market orientation, weather condition, etc. As reported by many researchers, 'question and answer service' was perceived as the best facility by majority of the farmers to get personalized solutions to their specific agricultural problems ${ }^{8}$.

\section{Widen Market Access}

One of the major drawbacks in Indian agriculture is complex distribution channels for marketing of agricultural produce. Farmers do not get acquainted with the updated prices of commodities, proper place for selling their inputs and consumer trends also. ICT has the great potential to widen marketing horizon of farmers directly to the customers or other appropriate users for maximum benefit. Farmers may connect directly with many users and may get information about current prices for their commodities. They can get access to the market sitting at home. Further, it will curtail the middle profit also which will be beneficial for the farmers. This can improve a farmer's source of revenue; empower farmers for making good decisions about appropriate future crops and commodities and marketing channels to sell their produce as well as to get inputs.

\section{Strengthen and empower farming community}

ICT technologies can help for strengthening farming communities through wide networking and collaborations with various institutes, NGO's and private sectors. Further, farmers may enhance their own capacities through updated information and wide exposure to scientific, farming and trade community.

\section{ICT Initiatives For Agricultural In India}

Approximately 45 per cent ICT projects of the whole world have been implemented in India and also maximum number of information kiosks has been employed in rural India ${ }^{7}$. Nevertheless, it was found that majority of the ICT projects in agriculture were put into action in socio- economically developed states of South and North India ${ }^{11}$, while deprived states are not benefitted by ICT initiatives. Some of the e-Agriculture initiatives in India are indicated below. 


\section{Agrisnet}

It is a comprehensive web portal to broadcast relevant information to farmers, which was initiated and funded by the Ministry of Agriculture, Government of India. The AGRISNET serves farming community by disseminating information and providing services through use of Information \& Communication Technology (ICT). It has following goals-

- $\quad$ Providing information to the farmers on quality of the inputs and its availability

- disseminating information of various government schemes and recommending fertilizers after soil testing

- $\quad$ Providing information on latest technologies for increasing productivity in agriculture.

\section{Digital green}

Digital Green is an international organization, which works with the participatory approach by engaging rural community to improve their livelihood using digital platform. Interactive and self explanatory videos are prepared for farmers by progressive farmers with the assistance of experts. These videos are shown to the farmers at individual level or in groups. The videos are prepared concentrating the requirements and welfare of the rural masses.

\section{eSagu}

The eSagu system was developed in 2004. eSagu provides customized solution to the farmers' problems and advice them from sowing to harvesting. Farmers send their farm condition in the form of digital photographs and videos, which were analyzed by the agricultural scientists and experts. After that, they suggest the right things to do to the farmers even small and marginal farmers are also getting advantage by this. The expert advice is conveyed to the concerned farmer within short time. The queries of illiterate farmers are dealt with the help of educated coordinators at village level. The farm situation or problem is communicated to the agricultural experts and they transmit accurate information to the farmers.

\section{Warana}

The Warana "Wired Village" project was instigated in 1998 by the Prime Minister's Office Information Technology (IT) Task Force with the objective of providing agricultural information and services to farmers for increasing productivity. The information is transmitted to the farmers in local language about prices of agricultural outputs, employment schemes from the government of Maharashtra and educational opportunities. The information is disseminated through information kiosks with the help of operators, who are the main linkage between the farmers and the agricultural connoisseurs.

\section{IKSL}

IFFCO KISAN SANCHAR LTD (IFFCO Kisan) was started in 2012. It delivers relevant information and custom-made solutions to the concerned farmers through voice messages on mobile phones. The farmers can also communicate directly to the agricultural experts on explicit themes via 'phone-in' programmes.

\section{Agmarknet}

Agricultural Marketing Information Network (AGMARKNET) was commenced in March, 2000 by Ministry of Agriculture, Government of India with the aim of empowering decision-making ability of the farmers regarding selling of their produce. This portal was developed to pace up the agricultural marketing system through broadcasting information about influx of agricultural commodities in the market and their prices to producers, consumers, traders, and policy makers transparently and quickly.

\section{iKisan}

iKisan is a web portal for transmitting information to the farmers about wide-ranging issues related to agriculture such as crop cultivation, weather forecast, agricultural inputs availability and quality, agriculture related financing institutions, soil quality and market updates.

\section{Digital Mandi}

Digital Mandi is an electronic trading platform for facilitating farmers and traders to sell and procure agricultural produce beyond the geographical and temporal limitations effortlessly. Various financial institutions also participate in online trading of agricultural output to remove cash crisis.

\section{eArik}

The eArik project was initiated in 2007 and it aims to disseminate climate smart agricultural practices and to achieve food security. It is an integrated platform to 
enhance the accessibility of agricultural information and technology in north-eastern India. It delivers agricultural specialist advice on crop cultivation, crop management and marketing. Farmers can also obtain information direct from the portal but field workers help farmers to access ICT -based information or to consult with other agricultural experts.

\section{Akashganaga}

This ICT project makes possible the milk collection, fat testing, and payment timely and user friendly manner. It augments the income generation of dairy farmers through incorporation of advanced technology.

\section{aAQUA (Almost All Questions Answered)}

aAQUA is a multilingual online system that facilitates farmers by advising them, solving their problems and answering their questions related to agriculture. Farmers have to register on aAQUA platform online or telephonically. After that, they can post their queries on the portal, for which they get answers shortly.

\section{Fisher Friend Mobile Advisory KCC}

The Fisher Friend Programme (FFP) of M S Swaminathan Research Foundation was launched in 2009 to protect fisher folk from occupational hazards and to empower their livelihoods. The relevant information on wave height, wind speed and director, potential fishing zones, relevant news, government schemes and market price is provided to fishermen in local language.

The FFP covers marginalized coastal communities in Tamil Nadu, Puducherry, Andhra Pradesh, Kerala, and Odisha, and is operational in English, Tamil, Telugu, Malayalam, Odiya languages.

\section{Reuters Market Light}

Reuters Market Light (RML) was initiated in October, 2007 to deliver customized information to the registered farmers via mobile-SMS. It disseminates information in eight local languages in 13 states $^{13}$.

\section{SMS Portal/mKisan Portal}

This portal is designed aiming to serve farmers in three ways -

- To disseminate information about diverse agricultural activities,
- $\quad$ To provide seasonal advisories and

- $\quad$ To provide various services directly to farmers through SMSs in their local languages.

The SMS Portal endows with a platform for amalgamation of service delivery under different sectors viz. Agriculture, Horticulture, Animal Husbandry and Fisheries.

\section{Mahindara Kisan Mitra}

This portal provides information to the farmers on price of commodities, weather forecast, crop advisories, loans, insurance, cold storage and warehouses along with success stories of progressive farmers.

\section{Kisan Call Centers (KCCs)}

KCCs were commenced on January 21, 2004 by the Department of Agricultural and Co-operation with the main intend of endowing extension services to the farming community in the local languages. The queries of farmers are tackled by agricultural graduates on help line, toll free number in their local language. The agricultural scientists also visit the field in person to get an idea about complex agricultural problems to resolve them.

\section{Village Knowledge Centers (VKCs)}

Village knowledge centers of MS Swaminathan research foundation, initiated in 1998 in Pondichery as a gateway of technical information related to agricultural inputs, price of outputs, crop rotation, use of fertilizers and pesticides. Information is disseminated through public address system.

\section{AGRONXT}

AgroNxt platform is multitasking platform for the farmers where farmers can get inputs, agriculture advice, weather condition etc. AgroNxt thrives to contribute to agriculture industry by delivering farmers usable, reliable and timely information that maximizes farm profitability. It assists upholding the agricultural productivity and sustainability.

\section{Major components used for ICT initiatives in India}

Major components which are used in our country for providing ICT services to the farmers are web portals, mobile applications on android phone, SMS and voice messages on simple phones, information kiosks, videos and video conferencing with the 
experts. Agriculture experts are the key component in the whole process of disseminating information to the farmers.

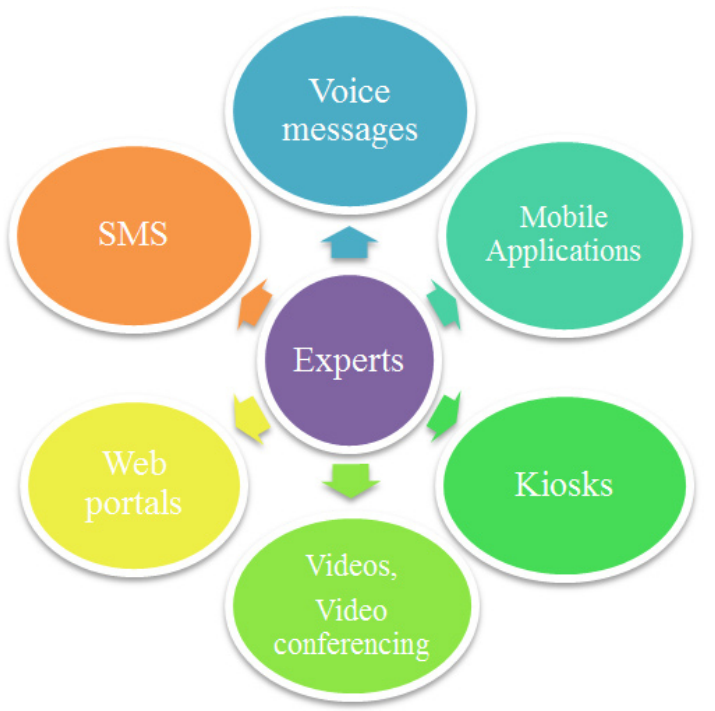

Fig. 1: Components used in ICT programmes in India

The ICT components may disseminate relevant, real, customized information to the farmers at appropriate time. Hence, ICTs provide a forum to reach masses easily and to make global and local information easily accessible to the stakeholders. Information dissemination in agriculture is cost effective, time saving and speedy through ICT${ }^{4}$. Mobile telephony has emerged as the foremost choice of the majority of the urban and rural people ${ }^{2}$. Mobile phones were found as the most widely accessed tool among the farmers for communication and for accessing agriculture-related information particularly for the marketing of produce ${ }^{5}$. Researchers also reported that mobile phones were the most used ICT tool and highly accessible by the farmers ${ }^{12}$. It was found in a comparative study that the livestock farmers of Uttar Pradesh, who were using ICT-based information made significantly better decisions on various livestock practices as compared to ICT non-users ${ }^{6}$. Further, few studies reported that the ICT based initiatives helped farmers of Madhya Pradesh, Uttar Pradesh and Tamil Nadu of India, in reducing transaction cost while acquiring information and doing transactions in input and output markets ${ }^{1}$.

\section{Framework of ICT in agriculture}

On review of the above mentioned ICT initiatives, a common framework was found to disseminate agriculture related information. Farmers are facilitated by field workers who coordinate communication between agriculture experts and farmers. However, farmers can directly access to agricultural information system. Agriculture experts are usually contacted only when required genuinely and coordinators are able to answer the queries. Use of ICT in agriculture is mainly to disseminate agriculture related information to the farmers and to trade their produce in India. Information is broadcasting online or offline. Internet is a major media for information flow.

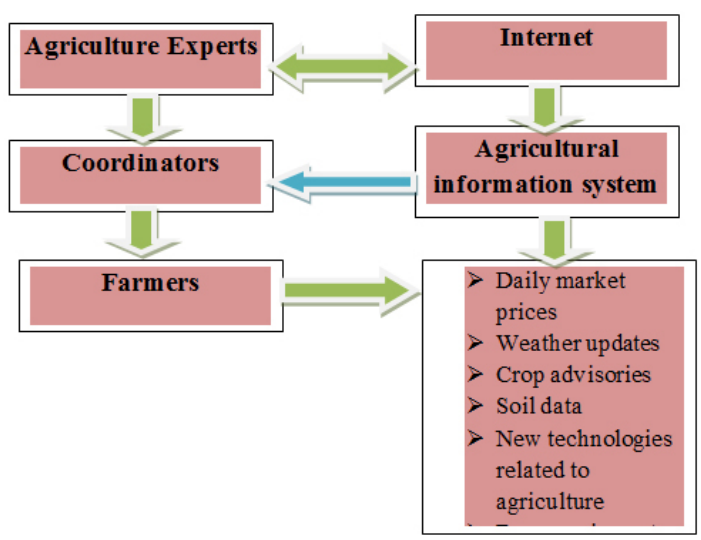

Fig. 2: Framework of ICT programmes in India

The ICT initiatives in India are based chiefly to disseminate information. In the current framework of ICTs, field coordinators as a link between farmers and information system are much needed due to many reasons. Sometimes, farmers are unable to browse information from the system or to comprehend the system. Field coordinators may send real farm situation to the experts or information system for their advices. This framework may be improved by including more advanced and high-tech approach in agriculture sector. Hence, another framework is proposed in the present paper.

\section{Proposed framework of ICT in Agriculture}

Not only agricultural technologies but many other spheres will be covered in the proposed framework such as educational methodologies for improving educational status of rural youth, health aspect, 
e-governance and employment alerts. Farming community, unemployed, poor and undernourished population of rural India will be benefitted by the ICT.
Presently, many ICT initiatives are based on spreading agricultural information among farmers, wherein agricultural experts are having key role. Different types of media are used to disseminate information.

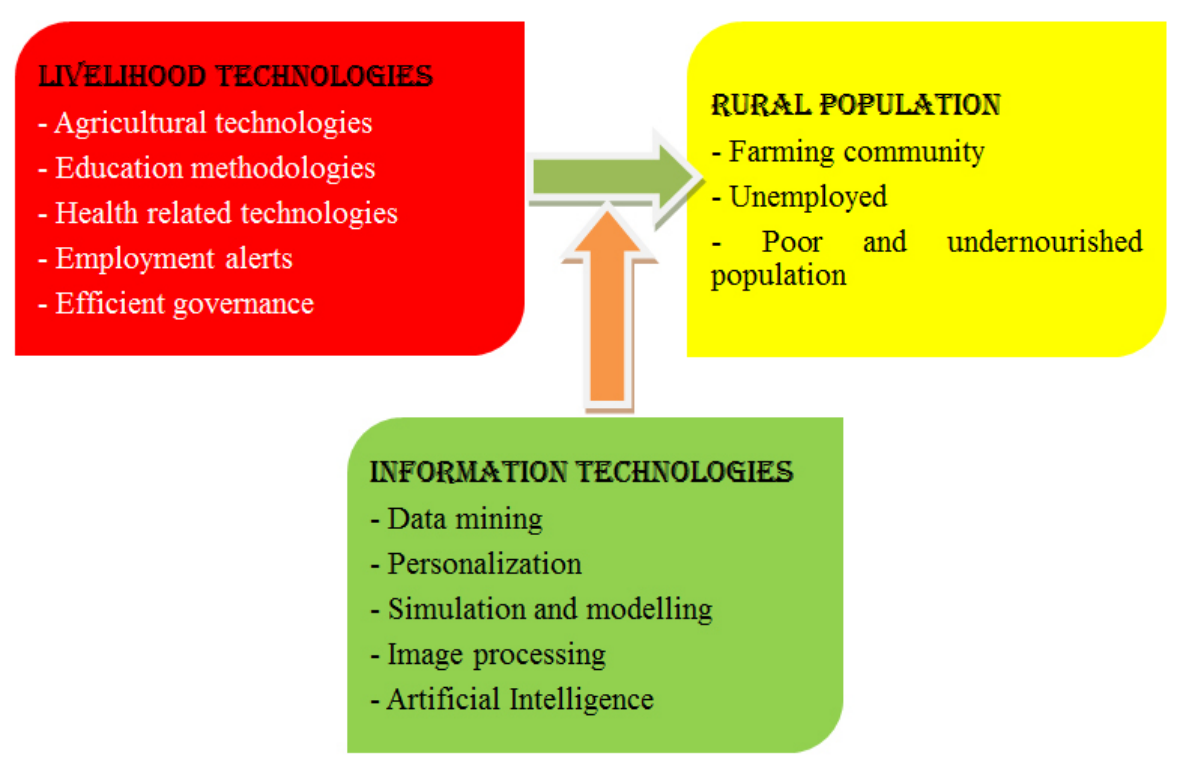

Fig. 3: Suggested framework of ICT programmes in India

Acceptance Model of Technology will be more useful and acceptable if it includes few more features such as security, customers' trust regarding information about agriculture as well as better infrastructure for speedy accessibility ${ }^{10}$.

More advanced information technologies will be used in the proposed framework of ICT. Data mining involves the process of finding large quantity of previously unknown data, and their use in important decision making. There are many applications of data mining such as division of market and customers into segments, defining different prices for individual customer segments, creating customer profiles that the organization desires to acquire.

Simulation and modelling will be used in agricultural mechanization. Applying cognitive technologies in agriculture may help to chose best crop, best seed according to farm condition and farmer's need. Image processing will be used to determine particular disease or pest for the crop and to send its remedies directly to the farmers. Imaging techniques will also be useful in determining the vegetative index, land mapping of irrigated area, type of weed grown in the area etc. with greater accuracies.

\section{Conclusion}

Agriculture is one of the indispensable sectors in our country. It is well known fact that ICT can revolutionize agriculture in many ways. ICT projects are yet to make any breakthrough in agricultural information dissemination and other areas. Deployment of ICTs needs to be stressed more. ICT for agricultural projects needs to be compared and evaluated precisely. It is need of hour to obtain apposite information through ICTs and to deploy advanced ICTs in agriculture.

Having reviewed and analyzed current ICTbased information service models, the following suggestions that are relevant to government organizations and ICT developers can be provided for future development and research:

- Evaluation of the effectiveness of existing strategies and policies to run ICT projects in agriculture based on the feedback of grass root level workers/officers working directly with farmers in rural regions.

- Transforming agriculture sector into the modern digital agriculture to further improve social and economical benefits. 
- Improving the digital access by farmers with technological advances and skills improvement.

- $\quad$ Adopting more advanced ICT tools in agriculture such as GPS, GIS, RFID, Remote sensing, Smart device for precision agriculture, sustainability, environment, food safety, etc.
Analysing and managing Big Data in agriculture.

\section{Conflict of Interest}

There is no conflict of interest with this manuscript.

\section{Acknowledgement}

The authors would like to extend gratitude to Sardarkrushinagar Dantiwada Agricultural University for this work.

\section{References}

1. Adhiguru, P. and Devi, S.V. ICT in Indian Agriculture: Learnings and way ahead. Int. J. of Ext. Edu.; 2012; 8:1-4

2. Ansari, M.A. and Pandey, N. 2011.Assessing the potential and use of mobile phones by the farmers in Uttarakhand (India): A special project report. G.B. Pant University of Agriculture and Technology, Pantnagar, India. Ansari, M.A. and Pandey, N. (2013) Assessing the potential and use of mobile phones in agriculture. Karnataka Journal of Agricultural Sciences, 26(3): 388-392.

3. Bahl, M. S\&T for Rural India and Inclusive Growth: ICT in Agricultural Marketing 2008 (http://www.nistads.res.in).

4. Chandrashekara, P., "Private Extension: Indian Way, Private Extension: Indian Experiences", 2001. National Institute of Agriculture Extension Management, Hyderabad, p. 25.

5. Chhachhar, A.R., Querestic, B., Khushk, G.M. and Ahmed, S. 2014 Impact of ICTs in Agriculture Development. J. of Bas. App. Sci. Res. 2014; 4(1):281-288.

6. Jabir, A. Use of quality information for decision -making among livestock Farmers: Role of ICT . Liv. Res. for R. Dev. 2011; 23 (3).

7. Manzar, O. Adversity to Success the World's Best e-Content and Creativity Experience. The Country Paper INDIA, Global ICT Summit. 2004; Digital Empowerment Foundation, Hong Kong.

8. Meera, Shaik N., Anita Jhamtani and Rao D.U.M., Information and Communication Technology in Agricultural Development: A
Comparative Analysis of Three Projects from India, Agricultural Research and Extension Network, 2004.Network Paper No. 135.

9. National Policy for Farmers, 2007. Department of Agriculture \& Cooperation, Ministry of Agriculture, Government of India. P. 15.

10. N. Jamaluddin, Adoption of E-Commerce Practices among the Indian Farmers, A Survey of Trichy District in the State of Tamilnadu, India, Procedia Economics and Finance 7. 2013; pp 140 - 149.

11. Paul, J., Katz, R. \& Gallagher, S. Lessons from the Field: An Overview of the Current Usage of Information and Communication Technologies for Development. 2004; P5-11. Digital Dividend/World Resources Institute, Bhttp://www.digitaldividend.org/pdf/lessons. pdf

12. Rebekka S., Saravanan R.: Access and Usage of ICTs for Agriculture and Rural Development by the tribal farmers in Meghalaya State of North-East India. J. of Agri. Infor. 2015; 6 (3):24-41.

13. RML (Reuters Market Light). 2010. Transforming the Indian Farming Community through Access to Intelligent information. Brochure.

14. Shalendra, K.C. Gummagolmath and Sharma P. ICT Initiatives in Indian Agriculture- An Overview, Ind. J. of Agri. Eco. 2011; 66 (3).

15. USAID, ICT to Enhance Farm Extension Service in Africa, Briefing Paper, November, 2010. 